\title{
The effects of Pinus brutia bark extract on pure and mixed continuous cultures of rumen bacteria and archaea, and fermentation characteristics in vitro
}

\author{
Ahu Demirtas ${ }^{1 *}$, Saad A. A. Musa ${ }^{2}$, Yasemin Salgirli-Demirbas², Hakan Ozturk², \\ Mert Pekcan', Nese N. Toprak ${ }^{4}$, Etkin Safak², Melis Unler², Begum Saral², and Mehmet B. Emre² \\ ${ }^{1}$ Department of Physiology, Faculty of Veterinary Medicine, Burdur Mehmet Akif Ersoy University, Burdur, Turkey \\ ${ }^{2}$ Department of Physiology, Faculty of Veterinary Medicine, Ankara University, Diskapi, Ankara, Turkey \\ ${ }^{3}$ Department of Biochemistry, Faculty of Veterinary Medicine, Ankara University, Diskapi, Ankara, Turkey \\ ${ }^{4}$ Department of Animal Science, Faculty of Agriculture, Ankara University, Diskapi, Ankara, Turkey
}

DEMIRTAS, A., S. A. A. MUSA, Y. SALGIRLI-DEMIRBAS, H. OZTURK, M. PEKCAN, N. N. TOPRAK, E. SAFAK, M. UNLER, B. SARAL, M. B. EMRE: The effects of Pinus brutia bark extract on pure and mixed continuous cultures of rumen bacteria and archaea, and fermentation characteristics in vitro. Vet. arhiv 91, 523-535, 2021.

\section{ABSTRACT}

The aim of the study was to investigate the effects of Pinus brutia bark extract, which is rich in polyphenolic compounds of tannins, on both pure and mixed continuous cultures of rumen bacteria and archaea, as well as on rumen fermentation characteristics in vitro. Antimicrobial susceptibility assay with pure cultures was carried out in an anaerobic chamber. Pinus brutia bark extract exhibited a potential inhibitor activity $(\mathrm{P}<0.05)$ against pure cultures of Ruminococcus flavefaciens, Eubacterium ruminantium, and Methanobacterium formicicum while a growth stimulatory effect $(\mathrm{P}<0.05)$ was observed for Ruminoccocus albus, Butyrivibrio fibrisolvens, and Streptococcus bovis. Pinus brutia bark extract only had a potential inhibitor effect $(\mathrm{P}<0.05)$ on $R$. albus at the highest dose $(1200 \mu \mathrm{g} / \mathrm{mL})$. Pinus brutia bark extract also stimulated $(\mathrm{P}<0.05)$ the growth of pure cultures of Fibrobacter succinogenes, while it did not affect Megasphaera elsdenii, except at the highest dose. The effects of two doses (75 and $375 \mathrm{mg} / \mathrm{L})$ of $P$. brutia bark extract on in vitro mixed cultures and rumen fermentation parameters were determined by the rumen simulation technique (Rusitec). Supplementation with P. brutia bark extract led to a quadratic decrease $(\mathrm{P}<0.05)$ in the cell numbers of $R$. flavefaciens. Production of total and individual short chain fatty acids (SCFA), acetate to propionate ratio $(\mathrm{C} 2 / \mathrm{C} 3)$, total protozoa, ruminal $\mathrm{pH}$, and dry matter digestibility (DMD) did not change in the presence of $P$. brutia bark extract. Supplementation with both doses of $P$. brutia bark extract decreased $(\mathrm{P}<0.05)$ the ammonia-N concentrations. Ammonia-N concentration was lowest in the high-supplemented group $(\mathrm{P}<0.05)$. As a conclusion, inhibitory effects of $P$. brutia bark extract on some species in the pure cultures were in the same direction as with mixed ruminal cultures, while stimulatory effects disappeared. The lack of inhibitory effects on protozoa and on a large number of Gram-positive rumen bacteria in the mixed cultures suggests that its mechanism of action is not exactly similar to antibiotics. Although P. brutia bark extract did not alter ruminal SCFA, it could have potential to improve ruminal protein utilization without depressing rumen microbial fermentation.

Key words: Pinus brutia bark; rumen bacteria; anaerobic chamber; rumen fermentation; rusitec; tannins

\footnotetext{
*Corresponding author:

Assoc. Prof. Dr. Ahu Demirtas, Department of Physiology, Faculty of Veterinary Medicine, Burdur Mehmet Akif Ersoy University, Istiklal Campus, 15030, Burdur, Turkey, Phone: +90 248213 2114; Fax: +90 248213 2001; E-mail: ahu-demirtas@hotmail.com
} 


\section{Introduction}

Rumen harbors a diverse ecosystem, consisting of bacteria, protozoa, fungi, archaea, and viruses which have an important role in the physiology, performance characteristics and welfare level of the host organism (LOOR et al., 2016). Rumen microorganisms have the capability to break down indigestible feedstuffs and to convert them to short-chain fatty acids and microbial protein. Rumen microbial fermentation also has some disadvantages, such as excessive $\mathrm{N}$ excretion and methane emission, which reduce the efficiency of feed utilization, and also cause environmental pollution (CALSAMIGLIA et al., 2007). Antibiotic growth promotors have been used to alter inefficient microbial processes by selectively inhibiting certain groups of microbes, mainly Gram-positive rumen bacteria, protozoa (HOOK et al., 2009), and methanogenic archaea (KHORRAMI et al., 2015). However, antibiotic growth promotors have been banned in Europe since 2006 due to the concern about the appearance of resistant strains of human pathogenic bacteria (GOIRI et al., 2009). After the ban on antibiotic feed supplements, plant extracts and plant secondary metabolites have come forward as alternatives to antibiotics to improve animal productivity.

Pinus brutia Ten. (Turkish red pine; brutia pine) grows naturally in the Mediterranean, Aegean, and Black Sea regions of Turkey. This species covers $25 \%$ of the total Turkish forest area and therefore, its bark has major potential in the wood working industry as a waste material (UCAR et al., 2013). Pinus brutia bark is rich in antimicrobial phenolic compounds, i.e. flavonoids and phenolic acids which are particularly the constitutive units of tannins (KIVRAK et al., 2013; UCAR et al., 2013). Resin present in the bark of plants is used for medicinal purposes, for instance, to treat abscesses or relieve pain (SEZİK et al., 2001). Previous research has shown that extracts of $P$. brutia bark has antimicrobial activity against Gram-positive bacteria such as Bacillus cereus, B. subtilis, B. megaterium, Staphylococcus aureus, and Mycobacterium smegmatis, while it was ineffective against Gram-negative species, Escherichia coli and Klebsiella pneumoniae (DIĞRAK et al., 1999).
However, the influences of $P$. brutia bark extract on rumen microorganisms and rumen fermentation have not been previously reported.

Determining the antimicrobial spectrum and the optimal dose are the major challenges in the rumen studies with plant extracts and plant secondary metabolites. Nonspecific and strong antimicrobial activity can depress ruminal fermentation overall, especially in high doses (BODAS et al., 2012). Therefore, this study aimed to investigate the effects of $P$. brutia bark extract on both pure and mixed continuous cultures of Gram-positive and Gramnegative rumen bacteria and rumen archaea, as well as on rumen fermentation characteristics in vitro.

\section{Materials and methods}

Plant extract. The extract of $P$. brutia bark was provided by the Kale Naturel Herbal Products Company, Ltd., Balikesir, Turkey. As specified by the manufacturer, bark samples were air dried, ground in a mill, and screened. Pinus brutia bark (powder) was extracted with distilled water $(1 / 10, \mathrm{w} / \mathrm{v})$ at $55^{\circ} \mathrm{C}$ for $6 \mathrm{~h}$ and filtered to give a homogenous liquid. The extract was reduced to $1 / 5$ of its volume using a rotary vacuum evaporator, and dried in a laboratory scale spray-dryer.

Table 1. Phenolic compounds of $P$. brutia bark extract

\begin{tabular}{|l|c|}
\hline Phenolic compounds & $\mu \mathrm{g} / \mathrm{g}$ \\
\hline Gallic acid & 2.2 \\
\hline Protocatechuic acid & 1.4 \\
\hline Catechin & 6.4 \\
\hline$P$-hydroxy benzoic acid & 0.9 \\
\hline Caffeic acid & 1.2 \\
\hline Epicatechin & 5.8 \\
\hline Vanilin & 0.4 \\
\hline$P$-coumaric acid & 0.2 \\
\hline Ferulic acid & 0.2 \\
\hline Quercetin & 17.7 \\
\hline Luteolin & 0.2 \\
\hline Kaempferol & 0.2 \\
\hline Apigenin & 0.3 \\
\hline
\end{tabular}

Analyses of phenolic compounds of P. brutia bark extract. Phenolic compounds (Table 1) 
of $P$. brutia bark extract were quantified using a high-performance liquid chromatography (HPLC) (Shimadzu, Japan) device equipped with a photodiode array detector. An Agilent Eclipse XDB-C18 $(250 \times 4.60 \mathrm{~mm}) 5 \mu \mathrm{m}$ column at $30^{\circ} \mathrm{C}$ and $0.8 \mathrm{~mL} / \mathrm{min}$ flow speed was used.

Antimicrobial susceptibility assay with pure cultures.

Culture of bacterial and archaeal strains in anaerobic medium. Ruminococcus flavefaciens (ATCC 49949), Ruminococcus albus (ATCC 27210), Eubacterium ruminantium (ATCC 17233), Butyrivibrio fibrisolvens (ATCC 19171), and Streptococcus bovis (ATCC 33317) were the Gram-positive bacteria species used in the tests. A mesophilic, methanogenic archaeon, Methanobacterium formicicum (ATCC 33274), was used as a methane producer. Megasphaera elsdenii (ATCC 25940) and Fibrobacter succinogenes (ATCC 19169) were the Gram-negative bacterial species tested. The anaerobic medium for bacterial and archaeal cultures was prepared under $\mathrm{CO}_{2}$ as previously reported (ORPIN, 1976). Bacterial and archaeal strains were grown at $37{ }^{\circ} \mathrm{C}$ for $24-$ $72 \mathrm{~h}$ under strictly anaerobic conditions (80\% nitrogen, $10 \%$ carbon dioxide, $10 \%$ hydrogen) in an anaerobic chamber (Whitley DG250, Don Whitley, West Yorkshire, UK).

Broth microdilution method. The antimicrobial activity assays of $P$. brutia bark extract were carried out using a broth microdilution method, following the Clinical and Laboratory Standards Institute guidelines (CLSI, 2016) in the anaerobic chamber. A stock solution of $P$. brutia bark extract $(100 \mathrm{mg} /$ $\mathrm{mL}$ ) was prepared by dissolving the extract in 50\% $(\mathrm{v} / \mathrm{v})$ ethanol. Serial 2-fold dilutions of the extract $(1200,600,300,150,75,37.5,18.8,9.4,4.7$, and $2.3 \mu \mathrm{g} / \mathrm{mL}$ ) were made from the stock solution in the growth medium. For broth microdilution, 200 $\mu \mathrm{L}$ of each dilution was distributed over a 96-well plate (Corning 3599, Flat bottom, USA), and $20 \mu \mathrm{L}$ of inoculum compromising $4 \times 10^{10}$ cell $/ \mathrm{mL}$ of the overnight culture, were added into each well. Each strain was tested in triplicate wells. At the same time, negative control wells without extract, and media control wells without microorganisms, were maintained for each set. The plates were incubated at $37^{\circ} \mathrm{C}$ for $24 \mathrm{~h}$ in the anaerobic chamber. Microbial growth was detected with a microplate reader at
$600 \mathrm{~nm}$ (Epoch, BioTek, USA). A significantly lower OD600 value compared to the control dose $(0 \mu \mathrm{g} / \mathrm{mL})$ was accepted as potential antimicrobial activity (KO et al., 2018) while a significantly higher value was accepted as a stimulatory effect (DAS et al., 2015).

\section{In vitro testing with mixed continuous cultures}

Experimental procedure. Rumen simulation technique (Rusitec) apparatus, a semi-continuous culture system, was used to simulate the rumen environment in the laboratory (CZERKAWSKI and BRECKENRIDGE, 1977). The system consisted of nine airtight vessels with $750 \mathrm{~mL}$ volume each. Vessels were immersed in a water bath maintained at $39^{\circ} \mathrm{C}$. Rumen content from a freshly slaughtered healthy two-year-old Brown Swiss bull with $500 \mathrm{~kg}$ mean body weight, was obtained from a commercial slaughter facility as the vessel inoculum. The rumen content was transported in warm $\left(39^{\circ} \mathrm{C}\right)$ thermos bottles to the Rusitec system within $30 \mathrm{~min}$. On the first day of the experiment, each vessel was filled with $750 \mathrm{~mL}$ of strained rumen liquor. Solid ruminal content $(80 \mathrm{~g})$ was weighed into a nylon bag (150 $\mu \mathrm{m}$ pore size; $80 \times 120 \mathrm{~mm}$ ), which was then placed inside the feed container in each vessel, together with a bag of experimental feed (4 g barley straw and $6 \mathrm{~g}$ commercial concentrate). According to the information obtained from the owner, the animal had been fed a diet (12 kg DM/day) consisting of $40 \%$ barley straw and $60 \%$ commercial vitamin and mineral supplemented concentrate for growing cattle. The same diet was also used for in vitro incubation trials (Table 2).

Table 2. Ingredients of the experimental diet used in the Rusitec as fed basis

\begin{tabular}{|l|c|c|}
\hline Nutrients, \% & Concentrate & Barley straw \\
\hline Dry matter & 93.41 & 93.40 \\
\hline Ash & 8.96 & 11.48 \\
\hline Crude fiber & 5.70 & 35.11 \\
\hline Crude protein & 13.90 & 3.37 \\
\hline Ether extract & 4.77 & 2.13 \\
\hline Organic matter & 84.45 & 81.92 \\
\hline $\begin{array}{l}\text { Nitrogen-free } \\
\text { extract }\end{array}$ & 60.08 & 41.31 \\
\hline $\begin{array}{l}\text { Metabolizable } \\
\text { energy }(\mathrm{MJ} / \mathrm{kg})\end{array}$ & 11.67 & 6.78 \\
\hline
\end{tabular}


The commercial concentrate consisted of corn, wheat bran, corn gluten feed, molasses, sunflower seed meal, barley, corn dried distillers grains, soya bean meal, vinasse, vegetable oil, calcium carbonate, sodium chloride, and a vitamin-mineral premix. On subsequent days, the feed bag that had remained 48 hours in each vessel was replaced by a new bag of feed. Fermentation vessels received a continuous infusion of a buffer ( $\mathrm{pH}$ 7.4) (DEMIRTAS et al., 2020) at a rate of $750 \mathrm{~mL} /$ day.

Experimental design. The incubation trial consisted of a 6-day adaptation period (Day 1-6) followed by a 6-day collection period (Day 7-12). The trial was conducted as a completely randomized design (CRD) with three treatments and three replicates per treatment. The extract was used at $75 \mathrm{mg} / \mathrm{L}$ (low dose) and $375 \mathrm{mg} / \mathrm{L}$ (high dose) according to the recommendations for in vitro screening studies (CALSAMIGLIA et al., 2007). (These doses correspond to 75 and $375 \mu \mathrm{g} / \mathrm{mL}$ in comparison with the doses used in the pure culture assays in the present study). The treatments consisted of no additives (control), $75 \mathrm{mg} / \mathrm{L}$, and $375 \mathrm{mg} / \mathrm{L}$ of $P$. brutia bark extract. Dried extract of P. brutia bark was added directly to the fermentation vessels.

Sample collection and analyses. Analyses of the dry matter (DM), crude protein (CP), crude fiber $(\mathrm{CF})$, ash, ether extract (EE) and organic matter contents of the experimental diets (Table 2) were performed according to the procedure of the AOAC (Association of Official Analytical Chemists) (2000). Nitrogen-free extract (NFE) was calculated as follows: $\mathrm{NFE} \%=\mathrm{DM}-(\mathrm{CP}+\mathrm{CF}+\mathrm{EE}+\mathrm{Ash})$ (VAN SOEST, 1982). Metabolizable energy was determined according to the Turkish Standards Institute (TSE, 1991) method.

The $\mathrm{pH}$ values of ruminal fluids in each fermentation vessel were measured daily during feed bag exchange using an epoxy body $\mathrm{pH}$ electrode (WD-35801-00, Oakton, USA) connected to a pH-meter (Ion 6, Acorn series, Oakton, USA).

Samples for SCFA and ammonia-N analyses were taken from the overflow flasks of the Rusitec which were placed into ice to prevent microbial activity and to preserve the fermentation products. Before keeping at $-20^{\circ} \mathrm{C}, 90 \mu \mathrm{L}_{2} \mathrm{H}_{2} \mathrm{SO}_{4}(12 \mathrm{~N})$ was added to $5 \mathrm{~mL}$ of samples for SCFA analyses. The SCFA were measured by HPLC (Dionex Summit P680, ASI100, USA) as described previously
(DEMIRTAS etal., 2019). Daily production of SCFA was calculated by multiplying the concentrations by the volume of effluent accumulated. Ammonia-N concentration was detected colorimetrically using the indophenol blue method, and absorbance was measured at $546 \mathrm{~nm}$ with a spectrophotometer (UV-150-02, Shimadzu, Japan) (CHANEY and MARBACH, 1962).

For protozoa counting, $1 \mathrm{~mL}$ of rumen fluid sample taken from the fermentation vessel was mixed with $1 \mathrm{~mL}$ of a solution of $0.6 \mathrm{~g}$ methyl green, $8 \mathrm{~g} \mathrm{NaCl}$, and $100 \mathrm{~mL}$ formaldehyde (37\%) filled up to $1000 \mathrm{~mL}$ with distilled water. Total numbers of protozoa were determined with a counting chamber (Fuchs-Rosenthal: $0.2 \mathrm{~mm}$ deep; $0.0625 \mathrm{~mm}^{2}$; Marienfeld, Germany) using a light microscope (Leica CME, USA).

After the 48 hour fermentation, the feed bags removed from the fermentation vessels were washed by squeezing gently in nylon bags containing $50 \mathrm{~mL}$ of buffer solution. The residual buffer in the nylon bags was transferred back to the fermenter to ensure transfer of solid-phase-associated microorganisms. The feed bags were dried at $65^{\circ} \mathrm{C}$ for $48 \mathrm{~h}$. The dry matter digestibility at $48 \mathrm{~h}$ was calculated from the difference between the original dry matter sample weight and the dry matter residue weight, divided by the original sample weight. This value was then multiplied by 100 to calculate the percentage digestibility of the dry matter (DEMIRTAŞ and PIŞKIN, 2020).

$D N A$ extraction and quantitative RealTime PCR (qRT-PCR) assay. Samples for DNA extraction were collected from the fermentation vessels on the 5th day of the collection period for rumen bacterial and archaeal profiling. Samples were taken from the fermentation vessels at the time of the feed bag exchange, therefore containing both planktonic and solid-phase-associated microorganisms (WATANABE et al., 2010). The samples were immediately placed in liquid nitrogen and stored at $-20{ }^{\circ} \mathrm{C}$ until processing. The samples were thawed and centrifuged at $10,000 \mathrm{rpm}$ for $10 \mathrm{~min}$ at room temperature. Pellets were resuspended in $2 \times$ phosphate-buffered saline (KHAFIPOUR et al., 2009). Total DNA extraction from the pellets was performed with an E.Z.N.A. ${ }^{\mathrm{TM}}$ stool DNA extraction kit (Omega BioTek, USA). 
A. Demirtas et al.: Effects of Pinus brutia bark extract on rumen bacteria, archaea, and fermentation in vitro

Table 3. Primers used in the qRT-PCR assay

\begin{tabular}{|c|c|c|c|}
\hline Target species & Forward primer $\left(5^{\prime}-3^{\prime}\right)$ & Reverse primer $\left(5^{\prime}-3^{\prime}\right)$ & References \\
\hline $\begin{array}{l}\text { Total bacteria } \\
(16 \mathrm{~S} \text { rRNA) }\end{array}$ & CGGCAACGAGCGCAACCC & CCATTGTAGCACGTGTGTAGCC & $\begin{array}{l}\text { Denman and } \\
\text { McSweeney, } \\
(2006)\end{array}$ \\
\hline $\begin{array}{l}\text { Methanogenic } \\
\text { archaea }(\operatorname{mcr} A)\end{array}$ & TTCGGTGGATCDCARAGRGC & GBARGTCGWAWCCGTAGAATCC & $\begin{array}{l}\text { Denman et al., } \\
(2007)\end{array}$ \\
\hline $\begin{array}{l}\text { HAP bacteria } \\
(16 \mathrm{~S} \text { rDNA) }\end{array}$ & GAGTTTGATCCTGGCTCAG & AAGGAGGTGATCCAGCC & $\begin{array}{l}\text { Attwood et al., } \\
(1998)\end{array}$ \\
\hline $\begin{array}{l}R . \text { albus } \\
(16 \mathrm{~S} \text { rDNA) }\end{array}$ & $\begin{array}{l}\text { CAAAACCCTAAAAGCAGTCT- } \\
\text { TAGTTCG }\end{array}$ & GACGGGCGGTGTGTACAAG & $\begin{array}{l}\text { Li et al., } \\
(2014)\end{array}$ \\
\hline $\begin{array}{l}\text { R. flavefaciens } \\
\text { (16S rRNA) }\end{array}$ & $\begin{array}{l}\text { C G A A C G G A G A T A A T T T - } \\
\text { GAGTTTACTTAGG }\end{array}$ & $\begin{array}{l}\text { CGGTCTCTGTATGTTATGAGG- } \\
\text { TATTACC }\end{array}$ & $\begin{array}{l}\text { Denman and } \\
\text { McSweeney, } \\
(2006)\end{array}$ \\
\hline $\begin{array}{l}\text { B. fibrisolvens } \\
\text { (16S rDNA) }\end{array}$ & ACACACCGCCCGTCACA & TCCTTACGGTTGGGTCACAGA & $\begin{array}{l}\text { Klieve et al., } \\
(2003)\end{array}$ \\
\hline $\begin{array}{l}\text { S. bovis } \\
\text { (16S rDNA) }\end{array}$ & CTAATACCGCATAACAGCAT & AGAAACTTCCTATCTCTAGG & $\begin{array}{l}\text { Tajima et al., } \\
(2001)\end{array}$ \\
\hline $\begin{array}{l}\text { F. succinogenes } \\
\text { (16S rRNA) }\end{array}$ & GTTCGGAATTACTGGGCGTAAA & CGCCTGCCCCTGAACTATC & $\begin{array}{l}\text { Denman and } \\
\text { McSweeney, } \\
(2006)\end{array}$ \\
\hline $\begin{array}{l}\text { M. elsdenii } \\
\text { (16S rDNA) }\end{array}$ & GACCGAAACTGCGATGCTAGA & CGCCTCAGCGTCAGTTGTC & $\begin{array}{l}\text { Ouwerkerk et } \\
\text { al., (2002) }\end{array}$ \\
\hline $\begin{array}{l}\text { S. ruminantium } \\
\text { (16S rDNA) }\end{array}$ & TGCTAATACCGAATGTTG & TCCTGCACTCAAGAAAGA & $\begin{array}{l}\text { Tajima et al., } \\
(2001)\end{array}$ \\
\hline
\end{tabular}

qRT-PCR: Quantitative Real-Time PCR; HAP bacteria: Hyper-ammonia producing bacteria

Purity and concentration of DNA were measured spectrophotometrically at A260/280 with the Take3 plate of a microplate reader (Epoch, BioTek, USA).

The quantification of representative rumen microorganisms was done with SYBRGreen based qRT-PCR assay using specific primers (Table 3 ) in a LightCycler 480II Real-Time PCR machine (Roche, Germany), as reported previously (DEMIRTAS et al., 2019). Melting curve analysis demonstrated that each of the primer pairs amplified a single product. The microbial numbers were calculated using the calibration curves, which were obtained according to the $\mathrm{Cp}$ values of known concentrations of the reference microorganisms for the respective target (JIAO et al., 2013).

Statistical analyses. A one-way ANOVA test was used for evaluation of the data from the antimicrobial assay, followed by Dunnet's test for comparison between the control and treatments. Each well of the 96-well plate was considered as an experimental unit.
A repeated analysis of variance (ANOVA) test was conducted using the SigmaStat Program (version 3.1, Systat Software, Erkrath, Germany) to analyze the data on the rumen fermentation characteristics. The individual fermenters were used as the experimental units. Treatments, time, and their interaction were considered as fixed effects, and fermenters as random effects. Post hoc multiple comparisons between means was conducted using the Duncan test.

Polynomial regression with sequential analysis of variance was used to assess the linear and quadratic effects of $P$. brutia bark extract dosage on rumen bacterial and archaeal populations in the Rusitec, determined by qRT-PCR.

Data on protozoa, bacteria and archaea were transformed by $\log _{10}$ before variance analysis. The differences were considered significant at $\mathrm{P} \leq 0.05$ for all data analyses. 


\section{Results}

Antimicrobial susceptibility of pure cultures. Effects of $P$. brutia bark extract on pure cultures of bacterial and archaeal strains are presented in Fig. 1 and Fig. 2. Pinus brutia bark extract exhibited potential antimicrobial activity $(\mathrm{P}<0.05)$ on $R$. flavefaciens at all used doses. Pinus brutia bark extract also showed potential antimicrobial activity $(\mathrm{P}<0.05)$ on E. ruminantium and M. formicicum at doses starting from 18.8 and $37.5 \mu \mathrm{g} / \mathrm{mL}$, respectively. Pinus brutia bark extract, on the other hand, showed a growth stimulatory effect $(\mathrm{P}<0.05)$ on $S$. bovis and B. fibrisolvens at doses starting
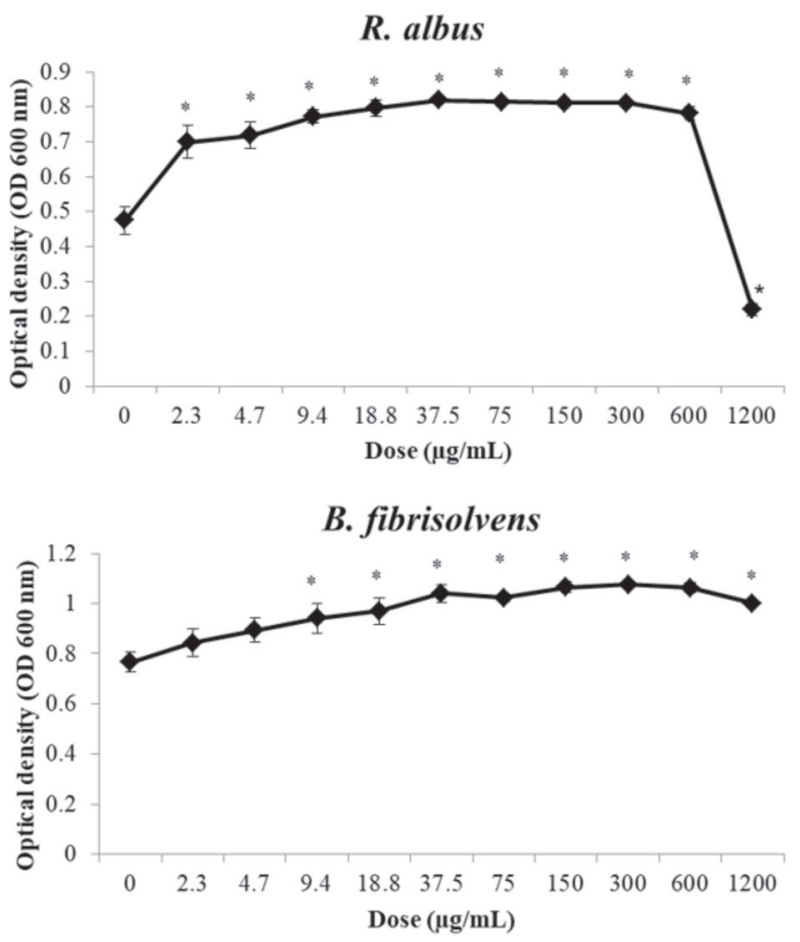

S. bovis

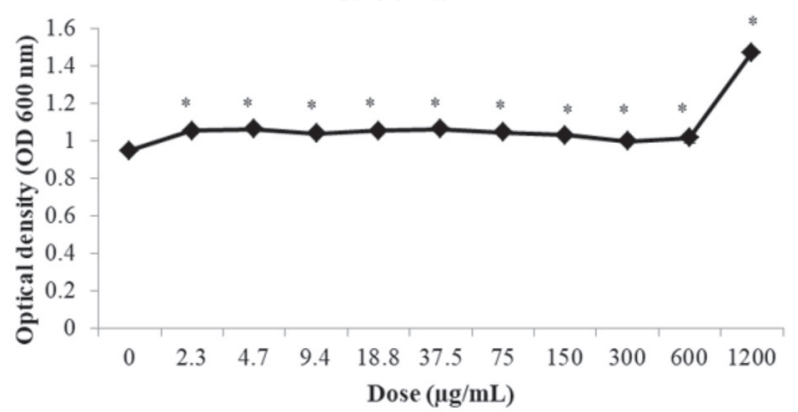

from 2.3 and $9.4 \mu \mathrm{g} / \mathrm{mL}$, respectively. The growth stimulatory activity of $P$. brutia bark extract on $S$. bovis was most obvious at the highest dose. The growth of $R$. albus was also promoted $(\mathrm{P}<0.05)$ by P. brutia bark extract at doses of $2.3-600 \mu \mathrm{g} / \mathrm{mL}$, while potential antimicrobial activity was observed at $1200 \mu \mathrm{g} / \mathrm{mL}(\mathrm{P}<0.05)$. Pinus brutia bark extract did not have any significant effect on $M$. elsdenii except at the highest dose, at which it had potential antimicrobial activity $(\mathrm{P}<0.05)$. On the other hand, it exhibited a growth stimulatory effect $(\mathrm{P}<0.05)$ on $F$. succinogenes, the other Gram-negative bacterium, at a dose starting from $4.7 \mu \mathrm{g} / \mathrm{mL}$.

\section{R. flavefaciens}

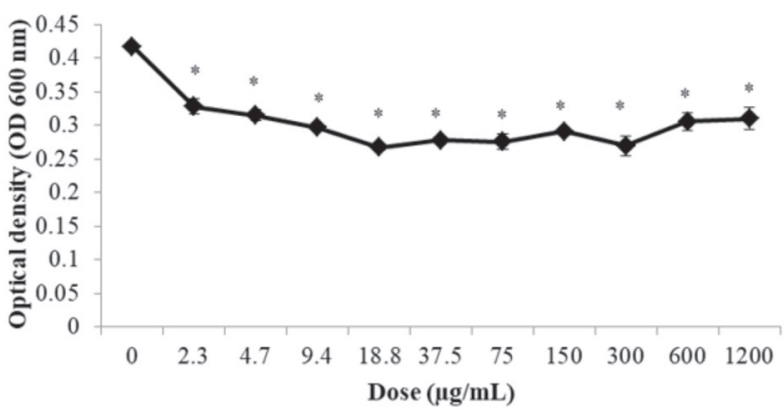

E. ruminantium

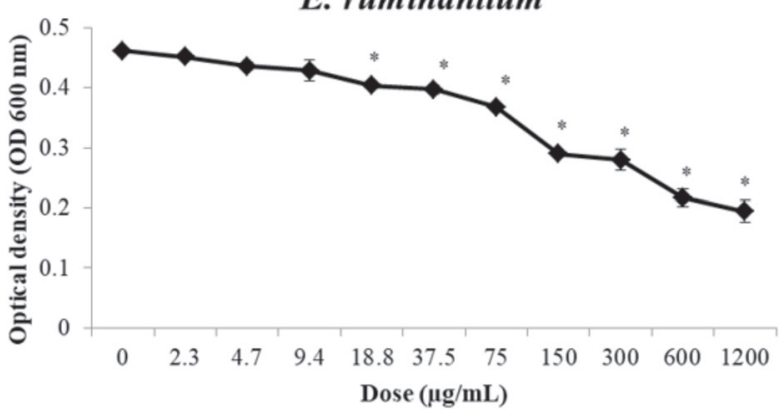

M. formicicum

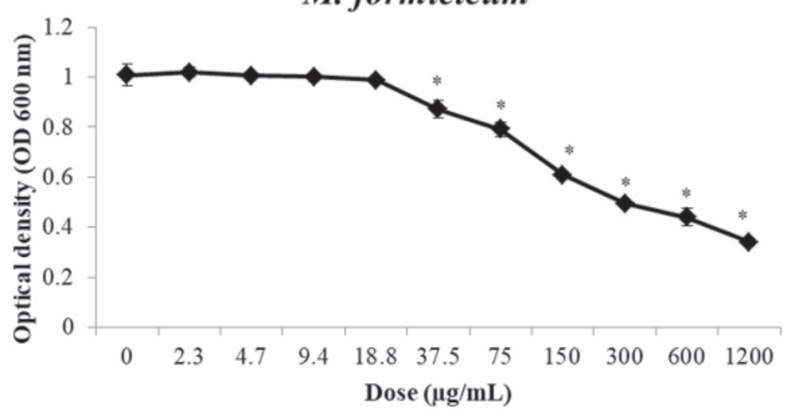

Fig. 1. Effects of P. brutia bark extract on pure cultures of Gram-positive rumen bacteria and methanogenic archaeon (M. formicicum) by the broth microdilution method. The results represent the mean \pm standard error. $* \mathrm{P}<0.05$, difference of $P$. brutia bark extract-treated culture compared with the control. 


\section{M. elsdenii}

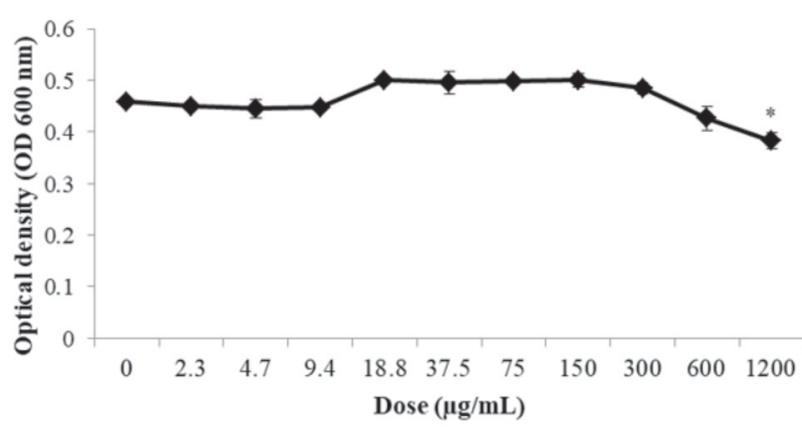

F. succinogenes

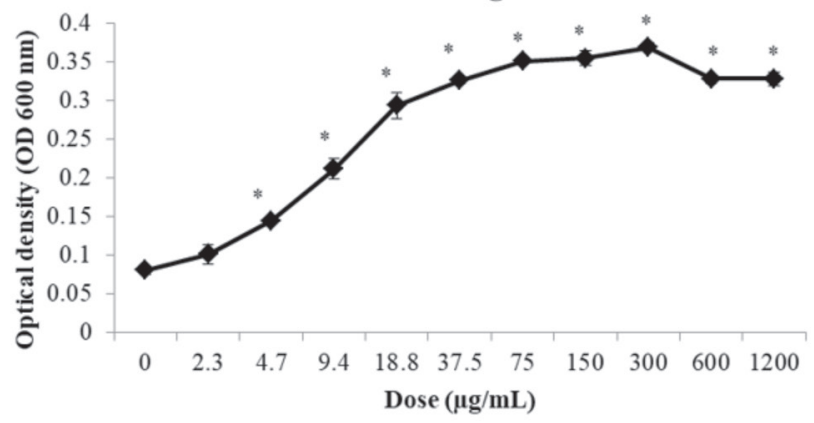

Fig. 2. Effects of $P$. brutia bark extract on pure cultures of Gram-negative rumen bacteria by the broth microdilution method. The results represent the mean \pm standard error. ${ }^{*} \mathrm{P}<0.05$, difference of $P$. brutia bark extract-treated culture compared with the control.

Table 4. Effects of two doses $(\mathrm{mg} / \mathrm{L})$ of $P$. brutia bark extract on rumen fermentation characteristics in the mixed continuous Rusitec cultures

\begin{tabular}{|l|c|c|c|c|c|c|c|}
\hline & \multicolumn{3}{|c|}{ Treatments } & \multicolumn{3}{c|}{ P values } \\
\cline { 2 - 4 } \cline { 7 - 8 } & Control & P. brutia-75 & P. brutia-375 & SEM & Treatment & Time & T $\times$ T \\
\hline Ruminal pH & 6.65 & 6.63 & 6.61 & 0.01 & 0.102 & 0.002 & 0.381 \\
\hline DMD (\%) & 49.51 & 52.17 & 50.35 & 1.66 & 0.547 & $<0.001$ & 0.272 \\
\hline $\begin{array}{l}\text { Protozoa } \\
\left(\log _{10} / \mathrm{mL}\right)\end{array}$ & 3.52 & 3.81 & 3.77 & 0.078 & 0.076 & 0.001 & 0.711 \\
\hline $\begin{array}{l}\text { Ammonia-N } \\
\text { (mmol/L) }\end{array}$ & $6.42 \mathrm{a}$ & $5.79 \mathrm{~b}$ & $5.00 \mathrm{c}$ & 0.13 & $<0.001$ & 0.008 & 0.608 \\
\hline $\begin{array}{l}\text { Total SCFA } \\
\text { (mmol/d) }\end{array}$ & 36.18 & 38.31 & 36.55 & 1.02 & 0.354 & 0.383 & 0.409 \\
\hline Individual SCFA & $(\mathrm{mmol} / \mathrm{d})$ & & & & & & \\
\hline Acetate & 18.34 & 19.80 & 19.27 & 0.47 & 0.167 & 0.412 & 0.757 \\
\hline Propionate & 8.82 & 9.43 & 8.82 & 0.46 & 0.588 & 0.540 & 0.259 \\
\hline Butyrate & 5.29 & 5.44 & 5.06 & 0.20 & 0.448 & $<0.001$ & 0.068 \\
\hline Isobutyrate & 0.30 & 0.31 & 0.28 & 0.03 & 0.829 & 0.155 & 0.635 \\
\hline Isovalerate & 1.11 & 1.08 & 1.02 & 0.05 & 0.434 & 0.217 & 0.263 \\
\hline Valerate & 2.33 & 2.26 & 2.11 & 0.10 & 0.328 & 0.040 & 0.123 \\
\hline C2/C3 & 2.10 & 2.10 & 2.28 & 0.10 & 0.375 & 0.170 & 0.513 \\
\hline
\end{tabular}

a-c: Means in the same row followed by different superscripts differ significantly $(\mathrm{P}<0.05)$. SCFA: Short chain fatty acids; $\mathrm{C} 2 / \mathrm{C} 3$ : acetate to propionate ratio; DMD: Dry matter digestibility; $\mathrm{T} \times \mathrm{T}$ : Treatment $\times$ Time interaction.

Rumen fermentation characteristics. The effects of two doses ( 75 and $375 \mathrm{mg} / \mathrm{L}$ ) of P. brutia bark extract on rumen fermentation characteristics in the mixed continuous Rusitec cultures are presented in Table 4. Supplementation with both doses of $P$. brutia bark extract decreased $(\mathrm{P}<0.05)$ the ammonia-N concentrations. Ammonia-N concentration was lowest in the high-supplemented group $(\mathrm{P}<0.05)$. Ruminal $\mathrm{pH}, \mathrm{DMD}$, total protozoa, production of total and individual SCFA, and $\mathrm{C} 2 /$ C3 did not change in the presence of P. brutia bark extract. 
Rumen bacterial and archaeal populations assessed by qRT-PCR. The effects of two doses (75 and $375 \mathrm{mg} / \mathrm{L}$ ) of $P$. brutia bark extract on rumen bacterial and archaeal populations in the Rusitec are shown in Table 5.
Supplementation with P. brutia bark extract led to a quadratic decrease $(\mathrm{P}<0.05)$ in the cell numbers of $R$. flavefaciens. Pinus brutia bark extract had no effect on the abundance of other microbial populations in the Rusitec.

Table 5. Effects of two doses (mg/L) of P. brutia bark extract on rumen bacterial and archaeal populations in the Rusitec determined by qRT-PCR ${ }^{1}$

\begin{tabular}{|l|c|c|c|c|c|}
\hline & \multicolumn{3}{|c|}{ Treatments } & \multicolumn{2}{c|}{ P values } \\
\hline $\begin{array}{l}\text { Microorganism } \\
\left(\log _{10} / \mathrm{mL}\right)\end{array}$ & Control & P. brutia-75 & P. brutia-375 & Linear & Quadratic \\
\hline Methanogenic archaea & $4.46 \pm 0.15$ & $4.41 \pm 0.09$ & $4.21 \pm 0.07$ & 0.086 & 0.979 \\
\hline Total bacteria & $9.41 \pm 0.07$ & $9.34 \pm 0.06$ & $9.37 \pm 0.03$ & 0.872 & 0.369 \\
\hline Gram-positives & $5.05 \pm 0.24$ & $4.79 \pm 0.23$ & $4.69 \pm 0.20$ & 0.337 & 0.525 \\
\hline HAP bacteria & $6.70 \pm 0.10$ & $6.60 \pm 0.07$ & $6.65 \pm 0.06$ & 0.909 & 0.361 \\
\hline R. albus & $0.28 \pm 0.07 \mathrm{a}$ & $0.07 \pm 0.02 \mathrm{~b}$ & $0.09 \pm 0.06 \mathrm{~b}$ & 0.159 & 0.030 \\
\hline R. flavefaciens & $5.02 \pm 0.09$ & $4.99 \pm 0.13$ & $5.07 \pm 0.12$ & 0.681 & 0.782 \\
\hline B. fibrisolvens & $3.46 \pm 0.43$ & $3.11 \pm 0.41$ & $4.18 \pm 0.11$ & 0.074 & 0.289 \\
\hline S. bovis & & & \multicolumn{2}{|c|}{} \\
\hline Gram-negatives & $4.90 \pm 0.26$ & $4.74 \pm 0.25$ & $5.03 \pm 0.22$ & 0.541 & 0.561 \\
\hline F. succinogenes & $7.47 \pm 0.12$ & $7.52 \pm 0.07$ & $7.43 \pm 0.07$ & 0.647 & 0.652 \\
\hline M. elsdenii & $6.15 \pm 0.76$ & $5.97 \pm 0.94$ & $6.60 \pm 0.43$ & 0.574 & 0.783 \\
\hline S. ruminantium & & & \\
\hline
\end{tabular}

${ }^{1}$ Values are means \pm SEM. $a, b$ : The different letters in the same row indicate statistical difference $(\mathrm{P}<0.05)$ between the means of treatments. qRT-PCR: Quantitative Real-Time PCR. HAP bacteria: Hyper-ammonia producing bacteria

\section{Discussion}

Manipulating rumen microbial populations by using antimicrobial feed additives has proved to be a favorable strategy to maximize production efficiency in ruminants. The selective activity of antimicrobial agents on microorganisms is critical in order not to suppress ruminal fermentation completely (BODAS et al., 2012). In the present study, the effects of $P$. brutia bark extract were investigated on both pure and mixed continuous cultures of some rumen microorganisms, to obtain a more detailed conclusion regarding the spectrum of antimicrobial action.

The P. brutia bark extract used in the present study contained several polyphenolic compounds, such as gallic acid, protocatechuic acid, cafeic acid, quercetin, catechin, and epicatechin (Table 1). The phenolic composition of P. brutia bark extract was in accordance with previous reports
(KIVRAK et al., 2013; UCAR et al., 2013). Phenolic acids and flavonoids determined in the P. brutia bark extract were generally identified as constitutive units of hydrolysable and condensed tannins (MCSWEENEY et al., 2001). Tannins are plant phenolics synthesized in plant parts, such as the bark, wood, roots, seeds, buds, leaves, and floral parts (BECHTOLD and MUSSAK, 2009). An extract of Turkish red pine bark was reported to contain 34\% tannin (BAYSAL et al., 2003).

In the present study, $R$. flavefaciens was the most susceptible bacterium to $P$. brutia bark extract, in both pure and mixed culture assays. Furthermore, P. brutia bark extract had potential to inhibit pure cultures of E. ruminantium among Gram-positive rumen bacteria and M. formicicum as a methanogenic archaeon. To our knowledge, 
there is no literature to date on the effects of $P$. brutia bark extract on rumen microorganisms. However, similar to our results, pure cultures of $R$. flavefaciens and E. ruminantium were also included in sensitive groups to Ginkgo extract, which is rich in polyphenols (OH et al., 2017). Ruminococcus flavefaciens was reported to be sensitive to cashew nut shell liquid, another phenolic-rich compound, both on pure cultures and in Rusitec experiments (WATANABE et al., 2010), as in the present study. Total populations of methanogenic archaea in Rusitec fermenters supplemented with $P$. brutia bark extract also tended to decrease linearly $(\mathrm{P}=0.086)$ in accordance with the pure culture experiments in the present study. The main flavonoid present in the P. brutia bark extract was quercetin (Table 1). OSKOUEIAN et al. (2013) reported that quercetin significantly suppressed in vitro populations of total methanogens in the rumen. The flavonoids generally act against microorganisms by inhibiting cytoplasmic membrane function, inhibiting microbial cell wall synthesis, or inhibiting nucleic acid synthesis (CUSHNIE and LAMB, 2005).

On the other hand, P. brutia bark extract stimulated the growth of some acetate, formate, butyrate, and lactate producing Gram-positive rumen bacteria, such as $B$. fibrisolvens, $R$. albus, and $S$. bovis in the pure culture experiments. A decrease in $R$. albus density was observed at the highest dose, while the increase in $S$. bovis was more prominent at the same dose. Streptococcus bovis was also one of the most resistant species among pure cultures of rumen bacteria to aldehydes from green leaf volatiles in a previous study (DEMIRTAS et al., 2019). Many studies have revealed that phenolic compounds can interact with microorganisms in a positive, as well as in a negative way, especially in anaerobic environments (DEMIRTAŞ and PISSKİN, 2020; BROUDISCOU and LASSALAS, 2000). Rumen bacteria can degrade many polyphenols, particularly constituents of tannins such as gallic acid, pyrogallol, phloroglucinol, and quercetin, to overcome the inhibitory effects of these compounds, and use the end products as carbon and energy sources (BHAT et al., 1998). CHESSON et al. (1982) reported that cellulolytic strains of rumen bacteria showed a considerable ability to hydrogenate trans-p-coumaric acid and trans-ferulic acids, with Ruminococcus spp. proving the most effective. The authors suggested that hydrogenation may serve to protect cellulolytic strains against the toxic effects of these phenolic compounds. TZOUNIS et al. (2008) indicated that the dietary polyphenols $(+)$-catechin and (-)-epicatechin can be utilized by beneficial fecal bacteria even in the presence of favorable carbon sources, such as sucrose and fructo-oligosaccharides. Quercetin, epicatechin, catechin, gallic acid, caffeic acid, and tannic acid did not inhibit probiotic L. acidophilus. Furthermore quercetin tended to stimulate the growth of $L$. acidophilus (HERVERT-HERNÁNDEZ et al., 2009).

Succinate and propionate producing Gramnegative rumen bacteria, $M$. elsdenii and $F$. succinogenes, were generally resistant to $P$. brutia bark extract in both pure cultures and mixed continuous cultures. Pure cultures of $M$. elsdenii were also previously reported to be insensitive to the phenolic-rich extracts $(\mathrm{OH}$ et al., 2017; WATANABE et al., 2010). The growth of $F$. succinogenes, on the other hand, was stimulated at all doses in the pure cultures. This effect, however, disappeared in the mixed continuous cultures (Rusitec). The same conflicting results between pure cultures and mixed cultures were also obtained for $R$. albus and B. fibrisolvens in the present study. The mechanism responsible for this effect could mainly be the competition for substrate utilization in the mixed ruminal cultures. Hence, the amount of end products from the degradation of the phenolic compounds may be insufficient to stimulate bacterial growth in the mixed cultures, in contrast to the pure cultures.

Pinus brutia bark extract supplementation did not affect the production of total and individual SCFA in the Rusitec. The abundance of bacterial species which are related to the production of SCFA also did not change, except for acetate and formate producing $R$. flavevaciens. Although the abundance of $R$. flavevaciens was depressed by $P$. brutia bark extract supplementation, acetate, valerate, and isovalerate production and DMD were not affected. This suggests that some other species which contribute to fiber digestion, such as Prevotella (STEVENSON and WEIMER, 2007) 
and/or uncharacterized fibrolytic bacteria replaced the suppressed bacteria, and potentially occupied this niche. The abundance of total bacteria also did not change in the Rusitec. The fact that the P. brutia bark extract does not affect total SCFA production and DMD indicated that it did not suppress ruminal fermentation. This is one of the expected properties of feed additives to be used for modification of ruminal fermentation (COBELLIS et al., 2016; BODAS et al., 2012).

Pinus brutia bark extract had remarkable effects on ruminal ammonia-N concentration in the present study. Ammonia-N concentrations declined by $9.8 \%$ and $22.1 \%$ in the presence of 75 and $375 \mathrm{mg} / \mathrm{L}$ P. brutia bark extract, respectively. A decrease in ruminal ammonia is preferred to improve feed $\mathrm{N}$ economy if the ammonia level is higher than the critical level for maintaining microbial protein synthesis (5 mg of N/dL) (GRISWOLD et al., 2003). The ammonia-N levels were $8.1 \mathrm{mg} / \mathrm{dL}$ and $7 \mathrm{mg} / \mathrm{dL}$ in the fermentation vessels supplemented with low and high doses of $P$. brutia bark extract, respectively. These levels were sufficient for microbial growth in the Rusitec. Inhibition of HAP bacteria and/or protozoa which contribute significantly to protein degradation in the rumen generally lowers the ruminal ammonia-N level (DEMIRTAS et al., 2019). However, the abundance of HAP bacteria and protozoa was not decreased by the P. brutia bark extract. The $P$. brutia bark extract used in this study contained several polyphenolics which are constitutive units of hydrolysable and condensed tannins, as mentioned before. It is well established that multiple phenolic hydroxyl groups of tannins bind proteins under the rumen $\mathrm{pH}$ conditions, and prevent the excessive degradation of proteins by microorganisms (BHATTA et al., 2015). This will increase protein availability/absorption in the small intestine (MCSWEENEY et al., 2001). WISCHER et al. (2013) reported that tannin-rich extracts from several plants and four tannin monomers reduced the ammonia- $\mathrm{N}$ accumulation in the Rusitec, as observed in this study. However, degradation of organic matter and dry matter was also reduced by tannin supplementation in that study. Tannins may reduce fibre digestion by complexing with lignocellulose and preventing microbial digestion, or by directly inhibiting cellulolytic microorganisms, or both (MCSWEENEY et al., 2001). The decrease in ammonia-N concentration without an adverse effect on DMD in the present study can be considered as positive in terms of the efficiency of rumen fermentation.

\section{Conclusions}

Pinus brutia bark extract exhibited potential inhibitor activity against pure cultures of some acetate- and formate-producing Gram-positive bacteria and methane producing archaeon. This effect was similar for some species in the mixed cultures. A growth stimulatory effect was also observed for some Gram-positive and Gramnegative bacteria. However, this effect disappeared in the mixed continuous cultures, probably because of the competition for substrate. Pinus brutia bark extract was also not effective enough to change SCFA profile in the Rusitec. Nevertheless, it decreased ruminal ammonia without depressing rumen microbial fermentation at the doses received. Therefore, P. brutia bark extract could have the potential to improve ruminal protein utilization. On the other hand, the fact that the extract had no inhibitory effect on protozoa and on many of Gram-positive rumen bacteria in the mixed cultures suggests that its mechanism of action is not exactly similar to antibiotics. The effects of higher doses of $P$. brutia bark extract can be investigated in future studies, and in vivo trials are required to validate its efficiency as a feed additive.

\section{References}

AOAC (ASSOCIATION OF OFFICIAL ANALYTICAL CHEMISTS) (2000): Official Methods of Analysis of AOAC International. $17^{\text {th }}$ ed., AOAC, USA.

ATTWOOD, G. T., A. V. KLIEVE, D. OUWERKERK, B. K. C. PATEL (1998): Ammonia-hyperproducing bacteria from New Zealand ruminants. Appl. Environ. Microbiol. 64, 1796-1804.

BAYSAL, E., M. K. YALINKILIC, M. ÇOLAK, O. GÖKTAŞ (2003): Combustion properties of Calabrian pine (Pinus brutia Ten.) wood treated with vegetable tanning extracts and boron compounds. Turk. J. Agric. For. 27, 245-252.

BECHTOLD, T., R. MUSSAK (2009): Handbook of Natural Colorants. John Wiley \& Sons, Ltd., Chichester, UK. 
BHAT, T. K., B. SINGH, O. P. SHARMA (1998): Microbial degradation of tannins-a current perspective. Biodegradation 9, 343-357.

BHATTA, R., M. SARAVANAN, L. BARUAH, C. S. PRASAD (2015): Effects of graded levels of tannin-containing tropical tree leaves on in vitro rumen fermentation, total protozoa and methane production. J. Appl. Microbiol. 118, 557-564.

DOI: $10.1111 /$ jam. 12723

BODAS, R., N. PRIETO, R. GARCÍA-GONZÁLEZ, S. ANDRÉS, F. J. GIRÁLDEZ, S. LÓPEZ (2012): Manipulation of rumen fermentation and methane production with plant secondary metabolites. Anim. Feed Sci. Tech. 176, 78-93.

DOI: 10.1016/j.anifeedsci.2012.07.010

BROUDISCOU, L. P., B. LASSALAS (2000): Effects of Lavandula officinalis and Equisetum arvense dry extracts and isoquercitrin on the fermentation of diets varying in forage contents by rumen microorganisms in batch culture. Reprod. Nutr. Dev. 40, 431-440.

DOI: $10.1051 /$ rnd:2000110

CALSAMIGLIA S., M. BUSQUET, P. W. CARDOZO, L. CASTILLEJOS, A. FERRET (2007): Invited review: essential oils as modifiers of rumen microbial fermentation. J. Dairy Sci. 90, 2580-2595.

DOI: $10.3168 /$ jds.2006-644

CHANEY, A. L., E. P. MARBACH (1962): Modified reagents for determination of urea and ammonia. Clin. Chem. 8, $130-132$.

DOI: $10.1093 /$ clinchem/8.2.130

CHESSON, A., S. S. COLIN, R. J. WALLACE (1982): Influence of plant phenolic acids on growth and cellulolytic activity of rumen bacteria. Appl. Environ. Microb. 44, 597603.

CLSI (CLINICAL AND LABORATORY STANDARDS INSTITUTE) (2016): M100-S26. Performance standards for antimicrobial susceptibility testing: $26^{\text {th }}$ Informational Supplement. Wayne, PA.

COBELliS, G., M. TRABALZA-MARINUCCI, Z. YU (2016): Critical evaluation of essential oils as rumen modifiers in ruminant nutrition: A review. Sci. Total Environ. 545, 556-568.

DOI: $10.1016 /$ j.scitotenv.2015.12.103

CUSHNIE, T. P. T., A. J. LAMB (2005): Antimicrobial activity of flavonoids, Int. J. Antimicrob. Ag. 26, 343-356.

DOI: 10.1016/j.ijantimicag.2005.09.002

CZERKAWSKI J. W., G. BRECKENRIDGE (1977): Design and development of a long term rumen simulation technique (Rusitec). Brit. J. Nutr. 38, 371-384.

DOI: 10.1079/BJN19770102

DAS, A., S. DATTA, S. MUKHERJEE, S. BOSE, S. GHOSH, P. DHAR (2015): Evaluation of antioxidative, antibacterial and probiotic growth stimulatory activities of Sesamum indicum honey containing phenolic compounds and lignans. LWT-Food Sci. Technol. 61, 244-250.

DOI: 10.1016/j.lwt.2014.11.044

DEMIRTAS, A., H. OZTURK, M. SUDAGIDAN, E. KEYVAN, O. YAVUZ, O.Y. GULAY, S. A. A. MUSA (2019): Effects of commercial aldehydes from green leaf volatiles (green odour) on rumen microbial population and fermentation profile in an artificial rumen (Rusitec). Anaerobe 55, 83-92.

DOI: 10.1016/j.anaerobe.2018.11.001

DEMIRTAŞ, A., İ. PİŞKİN (2020): Effects of Urtica dioica, Matricaria chamomilla, and Vitex agnus-castus extracts on in vitro rumen fermentation under normal and acidosis conditions. Ankara Univ. Vet. Fak. 67, 15-22.

DOI: 10.33988 /auvfd.561494

DEMIRTAS, A., S. A. A. MUSA, M. PEKCAN, Y. SALGIRLI DEMIRBAS, I. PISKIN, B. EMRE, N. TOPRAK, H. OZTURK (2020): Effects of cleavers (Galium aparine) and yarrow (Achillea millefolium) extracts on rumen microbial fermentation in in-vitro semi-continuous culture system (RUSITEC). Kafkas Univ. Vet. Fak. 26, 385-390.

DOI: $10.9775 / \mathrm{kvfd} .2019 .23283$

DENMAN, S. E., C. S. MCSWEENEY (2006): Development of a real-time PCR assay for monitoring anaerobic fungal and cellulolytic bacterial populations within the rumen. FEMS Microbiol. Ecol. 58, 572-582.

DOI: 10.1111/j.1574-6941.2006.00190.x

DENMAN, S. E., N. W. TOMKINS, C. S. MCSWEENEY (2007): Quantitation and diversity analysis of ruminal methanogenic populations in response to the antimethanogenic compound bromochloromethane. FEMS Microbiol. Ecol. 62, 313-322.

DOI: 10.1111/j.1574-6941.2007.00394.x

DIĞRAK, M., A. İLÇİM, M. HAKKI ALMA (1999): Antimicrobial activities of several parts of Pinus brutia, Juniperus oxycedrus, Abies cilicia, Cedrus libani and Pinus nigra. Phytother. Res. 13, 584-587.

DOI: 10.1002/(SICI)1099-1573(199911)13:7<584::AIDPTR508>3.0.CO;2-S

GOIRI, I., A. GARCIA-RODRIGUEZ, L. M. OREGUI (2009): Effect of chitosan on mixed ruminal microorganism fermentation using the rumen simulation technique (Rusitec). Anim. Feed Sci. Tech. 152, 92-102.

DOI: 10.1016/j.anifeedsci.2009.04.005

GRISWOLD, K. E., G. A. APGAR, J. BOUTON, J. L. FIRKINS (2003): Effects of urea infusion and ruminal degradable protein concentration on microbial growth, digestibility, and fermentation in continuous culture. J. Anim. Sci. 81, 329-336.

DOI: $10.2527 / 2003.811329 x$ 
HERVERT-HERNÁNDEZ, D., C. PINTADO, R. ROTGER, I. GOÑI (2009): Stimulatory role of grape pomace polyphenols on Lactobacillus acidophilus growth. Int. J. Food Microbiol. 136, 119-122.

DOI: 10.1016/j.ijfoodmicro.2009.09.016

HOOK, S. E., K. S. NORTHWOOD, A. D. G. WRIGHT, B. W. MCBRIDE (2009): Long-term monensin supplementation does not significantly affect the quantity or diversity of methanogens in the rumen of the lactating dairy cow. Appl. Environ. Microb. 75, 374-380.

DOI: 10.1128/AEM.01672-08

JIAO, Y., Y. DARZI, K. TAWARATSUMIDA, J. T. MARCHESAN, M. HASEGAWA, H. MOON, G. Y. CHEN, G. NÚŇEZ, W. V. GIANNOBILE, J. RAES, N. INOHARA (2013): Induction of bone loss by pathobiontmediated nod1 signaling in the oral cavity. Cell Host Microbe 13, 595-601.

DOI: 10.1016/j.chom.2013.04.005

KHAFIPOUR, E., S. LI, J. C. PLAIZIER, D. O. KRAUSE (2009): Rumen microbiome composition determined using two nutritional models of subacute ruminal acidosis. Appl. Environ. Microb. 75, 7115-7124.

DOI: 10.1128/AEM.00739-09

KHORRAMI, B., A. R. VAKILI, M. D. MESGARAN, F. KLEVENHUSEN (2015): Thyme and cinnamon essential oils: Potential alternatives for monensin as a rumen modifier in beef production systems. Anim. Feed Sci. Tech. 200, 8-16.

KIVRAK, I., S. KIVRAK, M. HARMANDAR, Y. ÇETINTAȘ (2013): Phenolic compounds of Pinus brutia Ten.: Chemical investigation and quantitative analysis using an ultra-performance liquid chromatography tandem mass spectrometry with electrospray ionization source. Rec. Nat. Prod. 7, 313-319.

KLIEVE, A. V., D. HENNESSY, D. OUWERKERK, R. J. FORSTER, R. I. MACKIE, G. T. ATTWOOD (2003): Establishing populations of Megasphaera elsdenii YE 34 and Butyrivibrio fibrisolvens YE 44 in the rumen of cattle fed high grain diets. J. Appl. Microbiol. 95, 621-630.

DOI: 10.1046/j.1365-2672.2003.02024.x

KO, H. H., R. R. LAREU, B. R. DIX, J. D. HUGHES (2018): In vitro antibacterial effects of statins against bacterial pathogens causing skin infections. Eur. J. Clin. Microbiol. 37, 1125-1135.

DOI: $10.1007 / \mathrm{s} 10096-018-3227-5$

LI, X., Z. DURMIC, S. LIU, C. S. MCSWEENEY, P. E. VERCOE (2014): Eremophila glabra reduces methane production and methanogen populations when fermented in a Rusitec. Anaerobe 29, 100-107.

DOI: $10.1016 /$ j.anaerobe.2013.10.008

LOOR, J. J., A. A. ELOLIMY, J. C. MCCANN (2016): Dietary impacts on rumen microbiota in beef and dairy production. Animal Front. 6, 22-29.

DOI: $10.2527 /$ af.2016-0030
MCSWEENEY, C. S., B. PALMER, D. M. MCNEILL, D. O. KRAUSE (2001): Microbial interactions with tannins: nutritional consequences for ruminants. Anim. Feed Sci. Tech. 91, 83-93.

DOI: $10.1016 / \mathrm{S} 0377-8401(01) 00232-2$

OH, S., R. SHINTANI, S. KOIKE, Y. KOBAYASHI (2017): Ginkgo fruit extract as an additive to modify rumen microbiota and fermentation and to mitigate methane production. J. Dairy Sci. 100, 1923-1934.

DOI: $10.3168 /$ jds.2016-11928

ORPIN, C. G. (1976): Studies on the rumen flagellate Sphaeromonas communis. J. Gen. Microbiol. 94, 270-280. DOI: 10.1099/00221287-94-2-270

OSKOUEIAN, E., N. ABDULLAH, A. OSKOUEIAN (2013): Effects of flavonoids on rumen fermentation activity, methane production, and microbial population. Biomed. Res. Int. 2013, 1-8.

DOI: $10.1155 / 2013 / 349129$

OUWERKERK, D., A. V. KLIEVE, R. J. FORSTER (2002): Enumeration of Megasphaera elsdenii in rumen contents by real-time Taq nuclease assay. J. Appl. Microbiol. 92, 753-758.

SEZIK, E., E. YEŞİLADA, G. HONDA, Y. TAKAISHI, Y. TAKEDA, T. TANAKA (2001): Traditional medicine in Turkey X. Folk medicine in central Anatolia. J. Ethnopharmacol. 75, 95-115.

STEVENSON, D. M., P. J. WEIMER (2007): Dominance of Prevotella and low abundance of classical ruminal bacterial species in the bovine rumen revealed by relative quantification real-time PCR. Appl. Microbiol. Biot. 75, 165-174.

DOI: 10.1016/S0378-8741(00)00399-8

TAJIMA, K., R. I. AMINOV, T. NAGAMINE, H. MATSUI, M. NAKAMURA, Y. BENNO (2001): Diet dependent shifts in the bacterial population of the rumen revealed with real- time PCR. Appl. Environ. Microbiol. 67, 2766-2774.

DOI: 10.1128/AEM.67.6.2766-2774.2001

TSE (TURKISH STANDARDS INSTITUTE) (1991): Animal Feeds. Metabolic energy determination (Chemical method). TSE. Publication No. 9610, Ankara, Turkey.

TZOUNIS, X., J. VULEVIC, G. G. C. KUHNLE, T. GEORGE, J. LEONCZAK, G. R. GIBSON, C. KWIK-URIBE, J. P. M. SPENCER (2008): Flavanol monomer-induced changes to the human faecal microflora. Brit. J. Nutr. 99, 782-792.

DOI: $10.1017 / \mathrm{S} 0007114507853384$

UCAR, M. B., G. UCAR, A. PIZZI, O. GONULTAS (2013): Characterization of Pinus brutia bark tannin by MALDITOF MS and 13C NMR. Ind. Crop Prod. 49, 697-704.

DOI: 10.1016/j.indcrop.2013.06.010

VAN SOEST, P. J. (1982): Nutritional Ecology of the Ruminant. $\mathrm{O}$ and $\mathrm{B}$ Books Inc., USA. 
WATANABE, Y., R. SUZUKI, S. KOIKE, K. NAGASHIMA, M. MOCHIZUKI, R. J. FORSTER, Y. KOBAYASHI (2010): In vitro evaluation of cashew nut shell liquid as a methane-inhibiting and propionate-enhancing agent for ruminants. J. Dairy Sci. 93, 5258-5267.

DOI: $10.3168 /$ jds.2009-2754
WISCHER, G., J. BOGUHN, H. STEINGAß, M. SCHOLLENBERGER, M. RODEHUTSCORD (2013): Effects of different tannin-rich extracts and rapeseed tannin monomers on methane formation and microbial protein synthesis in vitro. Animal 7, 1796-1805.

DOI: $10.1017 / \mathrm{S} 1751731113001481$

DEMIRTAS, A., S. A. A. MUSA, Y. SALGIRLI-DEMIRBAS, H. OZTURK, M. PEKCAN, N. N. TOPRAK, E. SAFAK, M. UNLER, B. SARAL, M. B. EMRE: Učinak eksrakta kore brucijskog bora (Pinus brutia) na čiste i mješovite kulture buražnih bakterija $\mathrm{i}$ arheja te na fermentacijske značajke buraga in vitro. Vet. arhiv 91, 523-535, 2021.

\section{SAŽETAK}

Cilj ovog rada bio je istražiti učinak ekstrakta kore brucijskog bora (Pinus brutia), koji je bogat polifenolnim sastojcima tanina, na čiste i mješovite kulture buražnih bakterija i arheja kao i na in vitro fermentacijske značajke buraga. Proveden je test antimikrobne osjetljivosti s čistim kulturama u anaerobnim uvjetima. Ekstrakt kore brucijskog bora pokazao je potencijalnu inhibitornu aktivnost $(\mathrm{P}<0,05)$ protiv čistih kultura bakterija Ruminococcus flavefaciens, Eubacterium ruminantium i Methanobacterium formicicum, a stimulacijski učinak na rast $(\mathrm{P}<0,05)$ opažen je za bakterije Ruminoccocus albus, Butyrivibrio fibrisolvens i Streptococcus bovis. Ekstrakt kore brucijskog bora imao je potencijalan inhibitorni učinak $(\mathrm{P}<0,05)$ na $R$. albus samo u najvećoj dozi $(1200 \mu \mathrm{g} / \mathrm{mL})$. Također je imao stimulacijski učinak $(\mathrm{P}<0,05)$ na čiste kulture Fibrobacter succinogenes, a nije utjecao na Megasphaera elsdenii osim u najvećoj dozi. Učinak dviju doza ( 75 i $375 \mathrm{mg} / \mathrm{L}$ ) ekstrakta kore brucijskog bora na in vitro mješovite culture i pokazatelje fermentacije u buragu određen je simulacijskom tehnikom (Rusitec). Dodatak ekstrakta kore brucijskog bora doveo je do kvadratnog smanjenja $(\mathrm{P}<0,05)$ broja stanica $R$. flavefaciens. Nije bilo promjena $\mathrm{u}$ proizvodnji ukupnih i pojedinačnih kratkolančanih masnih kiselina (SCFA), omjeru acetata i propionata (C2/C3), ukupnom broju protozoa, buražnom $\mathrm{pH}$ i probavljivosti suhe tvari (DMD). Suplementacija objema dozama ekstrakta kore brucijskog bora smanjila je $(\mathrm{P}<0,05)$ koncentracije amonijaka-N. Koncentracija amonijaka-N bila je najniža u skupini s najvećom dozom suplementa $(\mathrm{P}<0,05)$. Zaključujemo da je inhibitorni učinak ekstrakta kore brucijskog bora na neke vrste u čistim kulturama bio jednak onomu u mješovitim buražnim kulturama, a nije bilo stimulacijskog efekta. Manjak inhibitornih učinaka na protozoe i na mnoge Gram-pozitivne buražne bakterije u mješovitim kulturama upućuje na to da njihov mehanizam djelovanja nije jednak onomu kod antibiotika. Premda ekstrakt kore brucijskog bora nije promijenio buražni SCFA, mogao bi poboljšati iskorištavanje proteina u buragu a da pritom ne suprimira mikrobnu fermentaciju.

Ključne riječi: kora brucijskog bora; buražne bakterije; anaerobni uvjeti; buražna fermentacija; rusitec; tanini 
